\title{
The tale of a Trojan horse or the quest for market access? China and the World Trade Organization
}

\author{
O conto do cavalo de Troia ou uma busca por acesso \\ ao mercado? China e a Organização Mundial do Comércio
}

http://dx.doi.org/10.1590/0034-7329201400212

SVEN VAN KERCKHOVEN* ADRIAAN LUYTEN**

Rev. Bras. Polít. Int. 57 (special edition): 193-209 [2014]

\section{Introduction}

China has achieved remarkable economic progress over the last decades. It has managed nearly double-digit growth rates since the start of its economic reforms in 1978. In more recent years, these remarkable growth numbers have partly been the result of an aggressive export-oriented economic policy. Due to its economic growth and its size, China slowly became one of the major actors in the international trade system. As a result, China could not remain at the sidelines of the World Trade Organization (WTO), the main international organization and rule-setting body in international trade. After a prolonged negotiation process, China finally joined the WTO on 11 December 2001. Its accession looked bright for many WTO members, who saw the advantages of more limited trade policy interventions by the Chinese government and the resulting increased access to the growing Chinese market. As a major exporter, China had a lot to gain from WTO accession as well. First of all, WTO accession would provide Chinese firms better access to the markets of its major trade partners. Secondly, China would benefit from the stability of the trade regime provided by the WTO. As a WTO member, China would be able to challenge changes in the trade policy of other members, and therefore be less vulnerable to demand shocks induced by these policy changes. Finally, China would be allowed to take part in future WTO negotiations and hence have an influence of the international trade agenda. In spite of these mutual benefits, some observers opposed the Chinese accession to the WTO. They feared a Trojan Horse scenario, in which China would paralyze the WTO once its accession was approved (see, for example, Aaranson 2010).

* University of Leuven, Faculty of Economics and Business, Leuven, Belgium (sven.vankerckhoven@ggs.kuleuven.be).

** University of Leuven, Faculty of Economics and Business, Leuven, Belgium (adriaan.luyten@kuleuven.be). 
As in other areas, China's decision to play a more important role in international trade politics represents a trade-off: economic gains at the expense of less freedom in decisions regarding its trade policy. When China joined the WTO, it had to bring its trade policy in line with the WTO agreements and the commitments made by China in its accession protocol. If there exists uncertainty regarding the correct implementation of these rules, the WTO agreements allow other member states to initiate disputes regarding the perceived violation. This makes the WTO Dispute Settlement Understanding (DSU) the central element in providing security and predictability in the conduct of international trade (WTO DSU, Art. 3.2). The ability to initiate disputes at the WTO is both beneficial for China and the other WTO members. On the one hand, other WTO members can ensure that China lives up to the commitments it had made in its accession protocol and that it adheres to the WTO agreements. On the other hand, China observed the increasing number and variety of trade measures installed by other WTO members limiting the market access of Chinese exporters in these foreign markets. After joining the WTO, these measures can undergo WTO DSU scrutiny. However, after the Chinese accession, the WTO's dispute settlement system, risked to be flooded by disputes targeted towards and initiated by China (Goa 2007).

The debate whether China is a threat to global politics, and in particular to the WTO has attracted considerable attention from scholars, observers and policy makers (see for example Scott and Wilkinson (2013) for an overview). A wealth of literature has already studied the terms of China's WTO accession, and some research has addressed Chinese performance in the WTO DSU. We add to this by focusing on how well integrated China is within the WTO. We focus on the initial accession terms and their implementation afterwards, as observed by China's participation in the WTO DSU. This paper first looks into the accession of China to the WTO, with particular attention to the high terms that China agreed upon in its accession protocol, and the reasons why implementation of these commitments might be difficult. The second part investigates whether China has carried out these concessions and is abiding by the WTO agreements. We approach this issue by studying the WTO complaints in which China was involved, either as plaintiff or as defendant. We end with a short reflection on the achievements and challenges of China within the WTO framework, based on the previous sections. We argue that China has so far taken a very acquiescent approach. In recent years, this has shifted slightly as China has embarked on a tit-for-tat approach towards the WTO powerhouses, the United States (US) and the European Union (EU). After several disputes were initiated by these WTO members, China has started to responded with comparable complaints. In relation with other developing countries, China has been rather passive. It has not filed any disputes targeting these countries. We argue that the rise of China within the WTO has so far been rather peaceful, and hence disagree with those who consider China a Trojan Horse inside the WTO. The few disputes initiated by China are a way to preserve its market access in foreign markets, rather than a disruption of the WTO's functioning. 


\section{The Chinese accession}

Joining the WTO allows China to enjoy the benefits of reciprocal trade liberalizations, resulting in lower trade barriers and increased market access in foreign markets. ${ }^{1}$ Moreover, it has been argued that the Chinese accession provides the Chinese government with an externally enforced contract to credibly commit to domestic reforms. ${ }^{2}$ Bown (2010, p. 281) put it clearly when he argued that: "China agreed to undertake substantial import liberalization in exchange for greater certainty with respect to market access for its exports(...). China's program of reform would gain domestic credibility from trading partners' threat and actual use of WTO dispute settlement procedures to ensure that China was living up to its liberalization commitments."

China has been part of several bilateral trade agreements since the 1970s (in particular since the 1978 reforms). For example, in the late 1970s, it concluded trade agreements with the United States ${ }^{3}$ and the European Economic Community (the predecessor of European Union) ${ }^{4}$. It has also been active in the multilateral sphere, for example by being part of the Multi-Fiber Agreements. China also had a long history with the WTO and its predecessor, the General Agreement on Tariffs and Trade (GATT). China gained observer status in the GATT in 1986 as it tried to resume the Chinese membership that was held by Taiwan (see Breslin 2003 for more information). Resuming membership would have had the benefit of being automatically granted most favored nation status, while for newly acceding members, accession has to be negotiated. After it became clear that resuming membership would not be accepted, China tried to become a founding member of the WTO, when the latter was established in 1994. This attempt was once more not successful as the WTO powerhouses, such as the EU, US, and Japan requested significant conditions to be met before they would allow China to join the WTO. The main concerns were that Chinese goods market were not open enough, that China was reluctant to open its service market, and that it exercised strict control over state-owned enterprises (Lardy 1999). China failed to satisfy these conditions, and started a long negotiation period (approximately 15 years) ultimately resulting in the Chinese accession in 2001. Kong (2001) has argued that this long negotiation period reflects the gap between the status quo of China's trade policy and the WTO requirements. Irrespective of the extent to which China's trade policy diverged from WTO standards, a lengthy negotiation process could have been expected. Every country needs to go through an extensive

1 This is in particular the case for large countries, such as China. Economic theory has shown that small countries could benefit by unilaterally lowering their import barriers.

2 For more on the changes in China after the accession to the WTO, see Farah, 2006.

3 The Agreement on Trade Relations Between the People's Republic of China and the United States of America (7 July 1979).

4 The Trade Agreement between the European Economic Community and the People's Republic of China (03 April 1978). 
application process before becoming a WTO member. First, a working party is established by the General Council. This enables interested WTO members to review the applicant's trade policy. Second, the applicant country needs to conduct bilateral negotiations with all WTO members who have an interest in its economy. There are no fixed terms or set criteria that the applicant has to meet. These are established by the WTO members themselves in bilateral negotiations with the applicant country. Accession is hence a special bargaining position, whereby existing members can request almost anything from the acceding state, while the acceding country tries to limit its commitments. For a country of the size and economic power of China, the stakes of other WTO members are much higher, making the application process much more extensive than when a smaller economy joins the WTO (see Yamaoka 2013).

During its accession talks, it became clear that China had to make major concessions. ${ }^{5}$ Initially China wanted to accede as a developing country, but this was blocked by the main WTO members. As a result, China was required to make concessions significantly more deep-cutting than developing countries during their accession. For example, the Chinese binding tariffs are much lower than those of WTO members such as India and Brazil. This leaves the Chinese government with relatively little maneuver room, as its overhang (the difference between applied and allowed tariffs) is consequently very small. Moreover, a Transitional ProductSpecific Safeguard Mechanism (TPSSM) was included in China's accession protocol. ${ }^{6}$ This makes the threshold for the application of safeguard measures against Chinese products much lower than the terms required under the WTO Agreement on Safeguards. ${ }^{7}$ Thereby, other WTO members can to a certain extent discriminate against certain Chinese imports, because they are allowed to use safeguards measures on a variety of Chinese products for 12 years after its accession (until December 2013). Major WTO members requested the inclusion of this mechanism out of fear that their domestic markets would be flooded by Chinese products after China's accession (see Lee 2005). Furthermore, a Transition Review Mechanism (TRM) was integrated in the Chinese accession protocol, which was very unpopular in China (Farah 2006). The TRM monitored the implementation of the Chinese commitments on a yearly basis for the first ten years of membership. The TRM expired in 2010, after which China became part of the general Trade Policy Review Mechanism. ${ }^{8}$ On top of these imposed commitments, China was still considered a non-market economy by some WTO members. The categorization as a non-market economy increases the chances of anti-dumping investigations

5 Report of the Working party on the Accession of China (WT/ACC/CHN/49).

6 See section 16 of the Protocol of Accession of China (WT/L/432).

7 Rather than 'serious injury' which is the general threshold for allowing safeguard measures, 'market disruption/ material injury' is the threshold value for Chinese imports in the period of 12 years following the Chinese accession in 2001 .

8 For more information on the WTO-plus commitments and WTO-minus obligations, see Qin, 2003 and Yamaoka, 2013. 
on its products, through the price comparability mechanism. ${ }^{9}$ China received the traditional transition period for the implementation of specific commitments. It was entitled to three years to implement certain trade measures, periods up to four years to phase out certain non-tariff measures, and a transitional period of six years to implement certain GATS commitments. ${ }^{10}$

Compared to other accession protocols, the Chinese accession protocol was tailor-made in order to address the concerns of the other major WTO members. Its accession commitments were clearly higher than those of other new WTO members, both in coverage and in depth of market-opening.

The question remained whether and to what extent the Chinese government would be able to implement these deep-cutting commitments and reforms in its trade policy. In the end, by joining the WTO, a member has to adhere to about sixty different legally binding agreements and decisions. This is a huge and difficult task for all new members, but especially for a country like China which has historically taken the protection of national sovereignty as its prime foreign policy goal. First, several Chinese interest groups were to lose from the implementation of the WTO concessions. The implementation of the WTO agreements hence faced strong opposition from industries, local governments and the more conservative forces within the Chinese government (Fewsmith 2001). Many Chinese officials and interest groups still feared foreign competition and the free market. However, the more progressive elites within the Chinese CCP party had slowly gained the upper hand, and these were mainly concerned with getting access to the world's major consumer markets (Scott and Wilkinson 2013, 769). It has been argued that the more progressive regime is using the WTO accession to bind the hands of the more conservative powers within the Chinese government thereby ensuring deeper market reforms at home (Breslin 2003). Second, a relatively high share of China's GDP is produced by state-owned enterprises. The WTO agreements pay only little attention to state-owned enterprises. However, government control over state-owned enterprises can be in violation of the WTO agreements, if these companies do not behave "solely in accordance with commercial considerations," as stipulated in GATT Art. XVII. Third, corruption and the lack of transparency were still severe problems within China, and might have posed a risk to the functioning of the WTO. This is all the more important since the Chinese rule of law is weak, and still based on the tradition of guanxi (social connections). This is even enhanced by the strong bureaucracy that might have obstructed swift implementation of policy changes. Furthermore, China does not have a highly developed competition policy, making monopolies more likely. Both these issues

9 Under the Price Comparability in Determining Subsidies and Dumping section, importing countries can initiate anti-dumping measures on products originating from China for 15 years after its entry. In order to determine whether dumping has taken place, the domestic price in China will not necessary be taken in account. The Chinese producer will have to clearly prove that he is operating under market conditions in order for the domestic price to be taken as the benchmark (section 15 of the Protocol of Accession of China (WT/L/432)).

10 See the annexes to the Chinese accession protocol (WT/L/432). 
can once more undermine the most favored nation clause. Fourth, China lacks a decent environmental and labor policy, which might render their products more competitive vis-à-vis WTO member states that have these in place. The comparative advantage that China will receive in producing these products might result in more environmental pollution and cause problems to human health. In the end, this might be detrimental for China itself (Esty 2001). Fifth, Kong (2001, 1189) pointed out that there existed a risk that political concerns on the Chinese side (to issues such as Taiwan) might interrupt the WTO's agenda and the Chinese enforcement of the WTO agreements.

The previous paragraph shows that implementation of the WTO agreements and the Chinese commitments was not expected to be an easy task for China. Some expected that the Chinese accession would lead to a large number of WTO disputes, targeted against and initiated by China. Other WTO members could initiate many disputes when China has difficulties to live up to its commitments. China could file several complaints as well, in order to wash out some of the imbalances in its accession protocol. The fear existed that this would place too much of a burden on the WTO Dispute Settlement Body and would consequently disrupt the functioning of the WTO (Ostry 2003; Gao 2007). In the next section, we investigate how China has worked within the WTO by looking at the implementation and enforcement of WTO obligations in China and the enforcement of the market access of Chinese products.

\section{China and the enforcement of commitments through the WTO DSU}

\section{The WTO Dispute Settlement and China's increasing involvement}

When a country becomes a member to the WTO, it needs to ensure the conformity of its laws and policies with its WTO commitments and the WTO agreements. However, deviating from these gives a country some terms-of-trade gains. By strategically intervening in its trade policy, a country can support its domestic industry or get more tariff revenue. Under the WTO, the responsibility to detect this kind of illegitimate actions is assigned to fellow WTO members, who have to self-enforce their market access. ${ }^{11}$ When a country perceives a foreign trade barrier that hurts its domestic industry, it can file a complaint at the WTO. Initially, the parties to the dispute will discuss the perceived trade barrier during consultations. If no mutual agreeable outcome can be found in the course of these consultations, WTO panels can be established. In that case, a panel of experts will look into the issue and take the (legal) arguments of each side into account. After its investigations, the panel will rule on whether the trade barrier is in line with the WTO agreements. When either the complainant or the defendant believes that the

11 The WTO does conduct trade policy reviews on a regular basis, but these are often not detailed and updated enough to provide the other members with enough information in order to file a WTO complaint. 
panel has erred in its judgment, he can request the Appellate Body to rule on the legal basis of the panel's findings. The dispute will end either with the panel (or Appellate Body if requested) ruling the foreign trade policy in line with the WTO agreements, or in violation of the latter. In the latter case, the defendant will have to bring its policy in line with its WTO commitments and the WTO agreements. If the respondent fails to do so, the complainant can request the WTO to allow for the installation of countervailing measures (CVMs) to offset the economic loss of the illegitimate foreign trade policy.

After joining the WTO, China has slowly started using the WTO DSU, and has also been increasingly targeted in the WTO DSU (see picture 1). More specifically, China itself has filed 11 complaints at the WTO, and has been targeted 31 times. ${ }^{12}$ It has also been one of the most active third parties (102 cases), allowing it to remain updated with the legal aspects of rulings in different disputes. Being a third party in a WTO Dispute is an important leeway to more active involvement in the WTO (Davis 2012). A third party can join the consultations when it is interested in the matters the parties to a dispute are discussing in their consultations. There are various reasons for such an interest: for example, the third party may have a trade interest and feel similarly aggrieved by the challenged measure; it may, on the contrary, benefit from that measure; or it may be concerned about the challenge because it maintains a measure similar to that of the respondent. ${ }^{13}$

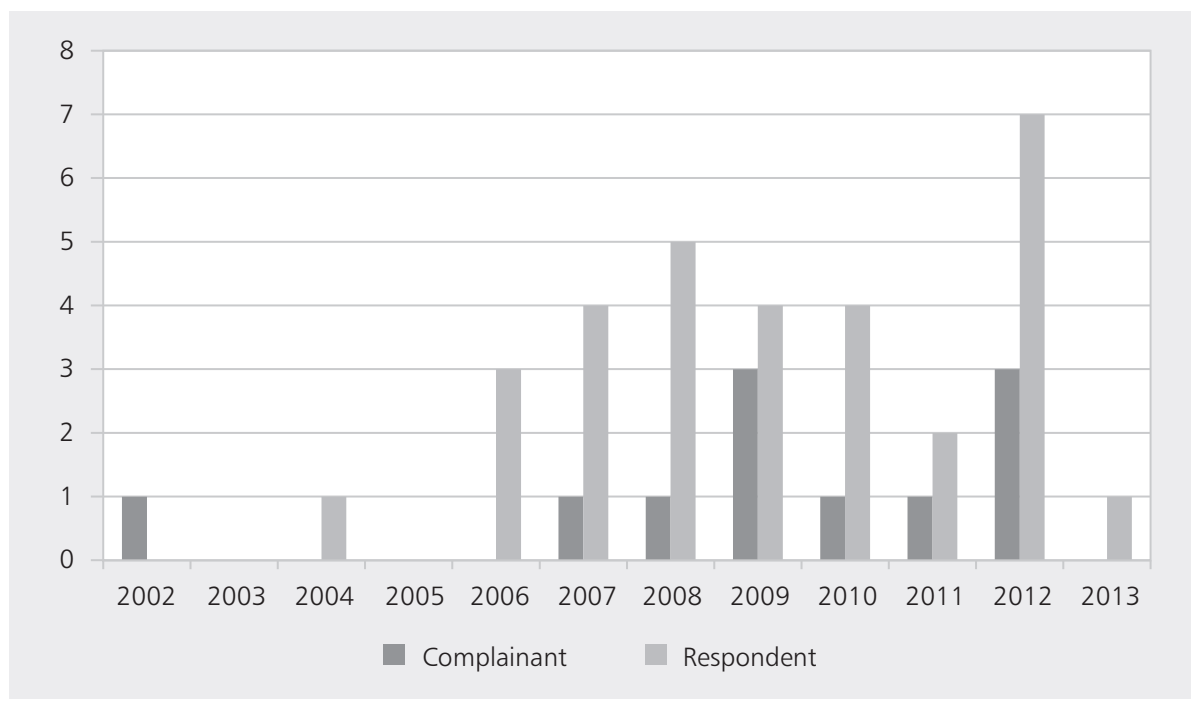

Figure 1. Chinese Involvement in the WTO DSU.

Source: WTO website.

12 For an in-depth overview of some of these disputes, see Ji and Huang (2011).

13 WTO Website available at <http://www.wto.org/english/tratop_e/dispu_e/disp_settlement_cbt_e/c6s2p2_e. htm\#third_parties>. 


\section{China as complainant}

Immediately after joining the WTO, China filed a case against the US regarding steel products. However, this was not an individual complaint, but a dispute in which China followed the lead of other WTO members, such as the EC, Japan and Brazil. After this initial dispute, China did not initiate any WTO disputes until 2007. Until now, China has filed 11 WTO complaints (see table 1). Given that China joined the WTO more than a decade ago, this is a relatively low number for one of the major global economies. So far, China has only challenged the USA ( 8 times) and the European Union (3 times). Generally, the cases filed by China have revolved around simple products, such as steel, poultry, paper, although recent cases also involve products related to for example solar energy (DS437, DS452). Complaints against the USA have mainly focused on the primary products, while complaints against the EU have targeted slightly more advanced products. Chinese complaints have mainly been concerned with anti-dumping measures and countervailing duties installed on Chinese products. ${ }^{14}$

As to the outcome of the Chinese WTO complaints, it is noteworthy that Chinese complaints have only very rarely been settled without the establishment of a WTO panel. Of all cases that can be considered as finished, ${ }^{15}$ only one complaint did not result in the establishment of a panel (or Appellate Body) ${ }^{16}$. All other disputes have been investigated by a WTO panel and in several cases the Appellate Body was invoked as well. In general, the WTO Disputes initiated by China have resulted in compliance by the defendant. In many of these disputes, the Chinese government is not yet convinced of full implementation by the respondent, and has left the door open for the installation of countervailing measures under WTO DSU Art. 21.5.

Table 1. China as complainant.

\begin{tabular}{|l|l|l|}
\hline Dispute & \multicolumn{1}{|c|}{ Respondent-Possible Foreign Trade Barrier } & Start Date \\
\hline DS252 & $\begin{array}{l}\text { United States - Definitive Safeguard Measures on Imports of } \\
\text { Certain Steel Products (Complainant: China) }\end{array}$ & 26 March 2002 \\
\hline DS368 & $\begin{array}{l}\text { United States - Preliminary Anti-Dumping and } \\
\text { Countervailing Duty Determinations on Coated Free Sheet } \\
\text { Paper from China (Complainant: China) }\end{array}$ & 14 September 2007 \\
\hline DS379 & $\begin{array}{l}\text { United States - Definitive Anti-Dumping and Countervailing } \\
\text { Duties on Certain Products from China(Complainant: China) }\end{array}$ & 19 September 2008 \\
\hline
\end{tabular}

14 For more information regarding anti-dumping measures imposed on Chinese products before and after the accession, see Bown (2010).

15 These are all the cases up to 28/02/2011.

16 This is case (DS368), which has been in the consultation phase for more than 6 years, and is hence probably settled bilaterally. 


\begin{tabular}{|c|c|c|}
\hline Dispute & Respondent-Possible Foreign Trade Barrier & Start Date \\
\hline DS392 & $\begin{array}{l}\text { United States - Certain Measures Affecting Imports of } \\
\text { Poultry from China (Complainant: China) }\end{array}$ & 17 April 2009 \\
\hline DS397 & $\begin{array}{l}\text { European Communities - Definitive Anti-Dumping } \\
\text { Measures on Certain Iron or Steel Fasteners from China } \\
\text { (Complainant: China) }\end{array}$ & 31 July 2009 \\
\hline DS399 & $\begin{array}{l}\text { United States - Measures Affecting Imports of Certain } \\
\text { Passenger Vehicle and Light Truck Tires from China } \\
\text { (Complainant: China) }\end{array}$ & 14 September 2009 \\
\hline DS405 & $\begin{array}{l}\text { European Union - Anti-Dumping Measures on Certain } \\
\text { Footwear from China (Complainant: China) }\end{array}$ & 4 February 2010 \\
\hline DS422 & $\begin{array}{l}\text { United States - Anti-Dumping Measures on Shrimp and } \\
\text { Diamond Sawblades from China(Complainant: China) }\end{array}$ & 28 February 2011 \\
\hline DS437 & $\begin{array}{l}\text { United States - Countervailing Duty Measures on Certain } \\
\text { Products from China (Complainant: China) }\end{array}$ & 25 May 2012 \\
\hline DS449 & $\begin{array}{l}\text { United States - Countervailing and Anti-dumping Measures } \\
\text { on Certain Products from China(Complainant: China) }\end{array}$ & 17 September 2012 \\
\hline DS452 & $\begin{array}{l}\text { European Union and Certain Member States - Certain } \\
\text { Measures Affecting the Renewable Energy Generation Sector } \\
\text { (Complainant: China) }\end{array}$ & 5 November 2012 \\
\hline
\end{tabular}

\section{China as respondent}

Until now, China has been targeted 31 times by other WTO members. In 2004, the USA initiated the first dispute against China, China-Value added tax on integrated circuits, to which China reacted by almost immediately revoking the contested measure. In the next dispute, China-Certain Measures Granting Refunds, Reductions, or Exemptions from Taxes and Other Payments, China took a similar approach and settled the issue with the complainants (the USA and Mexico) before the panel investigation was finished. In the next dispute, China-Measures Affecting Financial Information Services and Foreign Information Suppliers, China once more settled the issue during the consultations. Since only very few disputes were initiated by China, it is highly possible that China had settled other disputes with its trading partners even before a complaint was filed at the WTO. However, by 2006, China overcame its initial resistance to using the WTO DSU and demonstrated a willingness to allow for third party adjudication. This is also proven by the fact that China has so far always accepted the outcome of the panel/AB investigation.

The United States and the European Union have been most active in initiating disputes regarding the Chinese trade policy, with respectively 15 and 8 
complaints. Smaller economies, such as Mexico (4 complaints), Canada and Japan ( 2 complaints) and even Guatemala (1 complaint) have also been concerned with the consistency of the Chinese trade policy with the WTO agreements. In several cases, multiple countries have filed a complaint against the same perceived Chinese trade barrier. Thus, out of these 31 cases, only 20 cases are original. The original cases were filed by the USA (13 times), the EU ( 5 times), Mexico and Japan (each 1 time). It is clear that the US and the EU often take the lead in filing a complaint at the WTO, after which another member follows suit and files a slightly different complaint. When a panel is composed, this often results in a single panel for multiple similar complaints (WTO DSU Art. 9.1).

As can be seen in Table 2, the complaints against China cover a wide variety of products, from raw materials to audiovisual entertainment products. Complaints regarding the Chinese policy on the automobile sector have been filed the most (3 times). Similarly, the disputes concern a wide variety of measures installed by the Chinese government.

Table 2. China as respondent.

\begin{tabular}{|c|c|c|}
\hline No. & Measure & Start Date \\
\hline DS309 & $\begin{array}{l}\text { China - Value-Added Tax on Integrated Circuits } \\
\text { (Complainant: United States) }\end{array}$ & 18 March 2004 \\
\hline DS339 & $\begin{array}{l}\text { China - Measures Affecting Imports of Automobile Parts } \\
\text { (Complainant: European Communities) }\end{array}$ & 30 March 2006 \\
\hline DS340 & $\begin{array}{l}\text { China - Measures Affecting Imports of Automobile Parts } \\
\text { (Complainant: United States) }\end{array}$ & 30 March 2006 \\
\hline DS342 & $\begin{array}{l}\text { China - Measures Affecting Imports of Automobile Parts } \\
\text { (Complainant: Canada) }\end{array}$ & 13 April 2006 \\
\hline DS358 & $\begin{array}{l}\text { China - Certain Measures Granting Refunds, Reductions or } \\
\text { Exemptions from Taxes and Other Payments (Complainant: } \\
\text { United States) }\end{array}$ & 2 February 2007 \\
\hline DS359 & $\begin{array}{l}\text { China - Certain Measures Granting Refunds, Reductions or } \\
\text { Exemptions from Taxes and Other Payments (Complainant: } \\
\text { Mexico) }\end{array}$ & 26 February 2007 \\
\hline DS362 & $\begin{array}{l}\text { China - Measures Affecting the Protection and Enforcement of } \\
\text { Intellectual Property Rights(Complainant: United States) }\end{array}$ & 10 April 2007 \\
\hline DS363 & $\begin{array}{l}\text { China - Measures Affecting Trading Rights and Distribution } \\
\text { Services for Certain Publications and Audiovisual } \\
\text { Entertainment Products (Complainant: United States) }\end{array}$ & 10 April 2007 \\
\hline DS372 & $\begin{array}{l}\text { China - Measures Affecting Financial Information Services } \\
\text { and Foreign Financial Information Suppliers (Complainant: } \\
\text { European Communities) }\end{array}$ & 3 March 2008 \\
\hline
\end{tabular}




\begin{tabular}{|c|c|c|}
\hline No. & Measure & Start Date \\
\hline DS373 & $\begin{array}{l}\text { China - Measures Affecting Financial Information Services } \\
\text { and Foreign Financial Information Suppliers (Complainant: } \\
\text { United States) }\end{array}$ & 3 March 2008 \\
\hline DS378 & $\begin{array}{l}\text { China - Measures Affecting Financial Information Services } \\
\text { and Foreign Financial Information Suppliers (Complainant: } \\
\text { Canada) }\end{array}$ & 20 June 2008 \\
\hline DS387 & $\begin{array}{l}\text { China - Grants, Loans and Other Incentives (Complainant: } \\
\text { United States) }\end{array}$ & 19 December 2008 \\
\hline DS388 & $\begin{array}{l}\text { China - Grants, Loans and Other Incentives (Complainant: } \\
\text { Mexico) }\end{array}$ & 19 December 2008 \\
\hline DS390 & $\begin{array}{l}\text { China - Grants, Loans and Other Incentives (Complainant: } \\
\text { Guatemala) }\end{array}$ & 19 January 2009 \\
\hline DS394 & $\begin{array}{l}\text { China - Measures Related to the Exportation of Various Raw } \\
\text { Materials (Complainant: United States) }\end{array}$ & 23 June 2009 \\
\hline DS395 & $\begin{array}{l}\text { China - Measures Related to the Exportation of Various Raw } \\
\text { Materials (Complainant: European Communities) }\end{array}$ & 23 June 2009 \\
\hline DS398 & $\begin{array}{l}\text { China - Measures Related to the Exportation of Various Raw } \\
\text { Materials (Complainant: Mexico) }\end{array}$ & 21 August 2009 \\
\hline DS407 & $\begin{array}{l}\text { China - Provisional Anti-Dumping Duties on Certain Iron } \\
\text { and Steel Fasteners from the European Union (Complainant: } \\
\text { European Union) }\end{array}$ & 7 May 2010 \\
\hline DS413 & $\begin{array}{l}\text { China - Certain Measures Affecting Electronic Payment } \\
\text { Services (Complainant: United States) }\end{array}$ & 15 September 2010 \\
\hline DS414 & $\begin{array}{l}\text { China - Countervailing and Anti-Dumping Duties on Grain } \\
\text { Oriented Flat-rolled Electrical Steel from the United States } \\
\text { (Complainant: United States) }\end{array}$ & 15 September 2010 \\
\hline DS419 & $\begin{array}{l}\text { China - Measures concerning wind power equipment } \\
\text { (Complainant: United States) }\end{array}$ & 22 December 2010 \\
\hline DS425 & $\begin{array}{l}\text { China - Definitive Anti-Dumping Duties on X-Ray } \\
\text { Security Inspection Equipment from the European Union } \\
\text { (Complainant: European Union) }\end{array}$ & 25 July 2011 \\
\hline DS427 & $\begin{array}{l}\text { China - Anti-Dumping and Countervailing Duty Measures on } \\
\text { Broiler Products from the United States(Complainant: United } \\
\text { States) }\end{array}$ & 20 September 2011 \\
\hline DS431 & $\begin{array}{l}\text { China - Measures Related to the Exportation of Rare Earths, } \\
\text { Tungsten and Molybdenum(Complainant: United States) }\end{array}$ & 13 March 2012 \\
\hline DS432 & $\begin{array}{l}\text { China - Measures Related to the Exportation of Rare Earths, } \\
\text { Tungsten and Molybdenum(Complainant: European Union) }\end{array}$ & 13 March 2012 \\
\hline
\end{tabular}




\begin{tabular}{|c|l|c|}
\hline No. & \multicolumn{1}{|c|}{ Measure } & Start Date \\
\hline DS433 & $\begin{array}{l}\text { China - Measures Related to the Exportation of Rare Earths, } \\
\text { Tungsten and Molybdenum(Complainant: Japan) }\end{array}$ & 13 March 2012 \\
\hline DS440 & $\begin{array}{l}\text { China - Anti-Dumping and Countervailing Duties on Certain } \\
\text { Automobiles from the United States(Complainant: United } \\
\text { States) }\end{array}$ & 5 July 2012 \\
\hline DS450 & $\begin{array}{l}\text { China - Certain Measures Affecting the Automobile and } \\
\text { Automobile-Parts Industries (Complainant: United States) }\end{array}$ & 17 September 2012 \\
\hline DS451 & $\begin{array}{l}\text { China - Measures Relating to the Production and Exportation } \\
\text { of Apparel and Textile Products(Complainant: Mexico) }\end{array}$ & 15 October 2012 \\
\hline DS454 & $\begin{array}{l}\text { China - Measures Imposing Anti-Dumping Duties on High- } \\
\text { Performance Stainless Steel Seamless Tubes ("HP-SSST") from } \\
\text { Japan (Complainant: Japan) }\end{array}$ & 20 December 2012 \\
\hline DS460 & $\begin{array}{l}\text { China - Measures Imposing Anti-Dumping Duties on High- } \\
\text { Performance Stainless Steel Seamless Tubes ("HP-SSST") from } \\
\text { the European Union (Complainant: European Union) }\end{array}$ & 13 June 2013 \\
\hline
\end{tabular}

Source: WTO website.

Of the 31 disputes, 23 can be thought of as being finished (until 2012). 11 of these 23 are settled bilaterally, the other 12 have gone through at least the panel stage (of which the Appellate Body has ruled on 8). From the newer disputes (after 2012), a panel has been established for 6, while 2 more are still in consultations. If we look at unique disputes, 6 have been settled bilaterally, 5 have been investigated by WTO panels, and 3 have undergone Appellate Body scrutiny. Of the cases from after 2012, in 4 cases panels have been established, and 2 are still in the consultations phase. The high amount of bilaterally settled cases is striking. Goa (2007) pointed out that the high number of bilateral settlements in China's earlier years is due to the initial low profile China kept in its initial WTO cases. However, a few years and many disputes later, China's tendency to settle disputes bilaterally seems to be more of a pattern rather than just initial caution.

\section{Lessons for China from its involvement in the WTO DSU}

Some interesting observations can be made from China's involvement in the WTO DSU, both as complainant and as respondent. First, in the first years after its accession, very few disputes were initiated by China. Similarly, other WTO members did not file many complaints regarding the Chinese trade policy. This has changed since 2006. Since that year, China has even been the third most active player in the WTO DSU (Kennedy 2012). Several authors have argued that China has taken a more aggressive stand since 2008 (Bergsten 2008) and that it is on the road towards aggressive legalism (Gao 2007). Goa (2011) has argued that China 
is evolving from a passive taker of the existing rules to a country that might shake the rules for its own interests.

However, others have argued that this has not been a strategic choice, but that China rather has demonstrated a stubborn commitment to the preservation of the status quo and has reluctantly taken a more active role (Huang and Ji 2012; Scott and Wilkinson 2013). ${ }^{17}$ For Huang and Ji (2012), China's increase in WTO DSU litigation is the result of the difficulty it faced in amicably resolving critical issues bilaterally in the years leading up to 2008. For Don Harpaz, the rise in WTO cases is explained by an increased willingness of China to accept the authority of a third arbitrator. Traditional, litigation has been perceived as a sign of bad faith in China, and mediation was preferred (Don Harpaz 2010). China's assertiveness can also be perceived as a sign that China is better capable of dealing with WTO disputes. For example, China has invested considerable resources in developing legal capacity in dealing with the WTO (Huang and Ji 2012). Being a third party in many disputes has certainly also enabled China to gain more experience in dealing with the WTO DSU.

As a complainant, China practically only filed complaints regarding the discrimination of Chinese products in foreign markets. Most of the time, Chinese complaints have focused on anti-dumping measures. A prime Chinese concern is the fact that China can still be treated as a non-market economy in anti-dumping investigations. This has also been codified in China's WTO accession protocol's Article 15. This section allows other WTO members to initiate anti-dumping investigations, without a strict comparison to domestic prices in China when the producers under investigation cannot clearly show that market economy conditions prevail in the industry. This explains why the Chinese government has embarked on a big campaign seeking to be recognized as a market power, as observed by Huang and Ji (2012). Because major economies such as the EU and the US did not recognize China as a market economy, China felt that bilateral negotiations were not producing the right outcomes. Consequently, it has decided to invoke the WTO's DSU more frequently, thereby relying on an impartial arbitrator to settle disputes regarding the pricing in the domestic market. Huang and Ji (2012) have showed that the frustration with the lack of bilateral progress has also been reflected in official statements. Another main issue is the use of the China-Specific Safeguards, a series of measures temporarily allowed on Chinese products only. Both of these issues are directly related to two sections in the Chinese Accession Protocol (section 15/16 in the Chinese accession protocol). These sections explicitly allow for these practices, but China feels that these measures are extremely harsh, and has tried to address this through the use of the WTO DSU with a varying degree of success. China further objects to the "double remedy" approach that has

17 Our focus here is only on the Chinese usage of the WTO DSU, other papers have dealt with for example China's role in trade negotiations, and the access of new member states, see Huang and Ji, 2012 and Scott and Wilkinson, 2013. 
been used in the US, which is the practice of establishing countervailing duties and anti-dumping measures on the same products. ${ }^{18}$

Another reason why China is more actively using the WTO DSU is that it faces a certain number of "green" barriers when entering other markets, such as the markets of the EU and the US. Chinese exporters have a difficult time in meeting international and foreign environmental standards and regulations, but have to comply with these in order to be able to export. Due to these green barriers, China has not been able to get the expected benefits from joining the WTO (for an in-depth discussion, see Zhao 2007). The WTO indeed allows countries to protect human, animal or plant life and health, and to undertake measures related to the conservation for exhaustible natural resources (GATT. Art. XX, TBT Art. 2.2). By forcing China to adhere to certain environmental standards and regulations for the production of its exports, Chinese domestic standards are gradually getting stricter as well. It is to be expected that due to the pressure of its domestic industries, the Chinese government might increasingly challenge foreign green barriers, which might be driven by protectionist motivations.

So far, China has only taken up the challenge of initiating disputes against the two major WTO economies, the US and the EU. It has not yet filed a complaint against any other party or developing country, notwithstanding the fact that some of the latter have erected significant foreign trade barriers against China. For example, India has extensively used anti-dumping measures on Chinese products (Vandenbussche and Viegelahn 2013). China seems to have adopted a dual strategy. Vis-à-vis the WTO powerhouses (the EU and the US), China seems to have taken up a tit-for-tat approach. China's first WTO complaint against the US followed after the initiation of three successive US complaints in a short term. Similarly, China's first complaint against the EU, followed after three EU complaints. Towards developing countries, China has been using a more permissive and friendly approach.

China has faced strong opposition every time it filed a complaint. Almost every Chinese complaint ultimately resulted in panel or Appellate Body involvement. In many of these cases, the other party (US or EU) in the end implemented the WTO judgment (when ruled in favor of China). However, in several of these cases, the Chinese government is not yet convinced of full implementation and leaves the door open for the installation of countervailing measures under WTO DSU Art. 21.5. In the disputes where China acted as a respondent, it is remarkable that China has settled many cases bilaterally, rather than requesting the WTO panels to look into the case. Also, in the first years after its accession to the WTO, China settled a number of cases bilaterally without involving the WTO (see Ji and Huang 2011; Kennedy 2012). Since China is increasingly developing the capacities and experience to deal with WTO disputes, it might be expected that

18 See US-Anti-Dumping Measures and Countervailing Measures (DS 379). 
China will resort to the WTO panels more often in the future. As the TPSSM is soon expiring, China might use the WTO DSU more extensively to ensure that the initial safeguards installed on its products are removed. Moreover, China might in the long term also reconsider its strategy towards developing countries. Its permissive approach might change into a more approach focused on ensuring the market access of its products.

\section{Conclusion}

China's accession and its emergence as a major player within the WTO's its dispute settlement (in particular form 2006 on) is the most significant change in the identity of the system's top participants since the establishment of the WTO. The initial fears about China's accession seem to be unjustified. There is very little evidence that China is disturbing the functioning of the WTO. Before joining the WTO, the Chinese government could steer its economy and its exports by strategically intervening in its trade policy. This is currently no longer the case since the WTO agreements and the concessions WTO members have made towards their fellow WTO members seriously limit the extent and the amount of trade interventions a country can exercise. Joining the WTO hence required a step away from the traditional Chinese trade policy. This was even more outspoken as China had to accept very stringent terms in order to join the WTO, terms which are more extensive than in most other accession protocols. Considering the WTO complaints targeting China, it looks like China has implemented the very stringent measures to which it agreed upon its accession relatively well. Over the years, as China became more vested into the WTO and its agreements, it started to attack some measures levied by other WTO members on its products. This has especially been the case for the anti-dumping measures.

China needs to be active in the litigation process for both domestic and foreign policy measures. Internally, there is still a lot of criticism on the conditions to which China agreed when joining the WTO. Observers have often pointed out that some of the concessions made by China are unfair and imbalanced. In order to keep popular support for the decision to join the WTO, China needs to be on the more aggressive side from time to time, to show that its economy benefits from it, and that it would stand up to illegitimate foreign trade barriers. The possibility to raise complaints at the WTO also provides more confidence to Chinese producers that they will be treated equally in third countries.

Over the years, China has learned how to better work within the WTO and its DSU. After settling the first disputes bilaterally, China is now no longer afraid of going through the complete dispute settlement system, and has so far implemented the decisions of the WTO panels without much resistance. In its disputes with the US and the EU, China seems to have changed its strategy to a tit-for-that approach, and is not reluctant to file complaints against these two major 
economies. Even though China accepted very high commitments when it joined, it has by now demonstrated its willingness to put these into question. However, this has only been the case vis-à-vis the US and the EU, and China remains reluctant to initiate proceedings against other developing countries.

\section{Bibliographic references}

Aaranson, S.A. (2010). Is China Killing the WTO?, The International Economy, Winter 2010, pp. $40-41,67$.

Bergsten, F. (2008). A Partnership of Equals, Foreign Affairs, 87(2), pp. 57-69.

Breslin, S. (2003). Reforming China's Embedded Socialist Compromise: China and the WTO, Global Change, Peace and Security, 15(3), pp. 213-229.

Bown, C.P. (2010). China's WTO entry: Antidumping, Safeguards and Dispute Settlement, in Feenstra, R.C. and Wei, S.-J. (eds.) China's Growing Role in World Trade. University of Chicago Press.

Davis, C.L. (2012). Why Adjudicate? Enforcing Trade Rules in the WTO. Princeton University Press.

Don Harpaz, M. (2010). Sense and Sensibilities of China and WTO Dispute Settlement, Journal of World Trade, 44(6), pp. 1155-1186.

Esty, D.C. (2001). Bridging the Trade-Environment Divide, Journal of Economic Perspectives, 15(3), pp. 113-130.

Farah, P.D. (2006). Five years of China's WTO membership: EU and US perspectives on Chinas Compliance with transparency commitments and the transitional review mechanism, Legal Issues of Economic Integration, 33(3), pp. 263-304.

Fewsmith, J. (2001). The Political and Social Implications of China's Accession to the WTO, China Quarterly, 167, pp. 573-591.

Goa, H. (2007). Taming the Dragon: China's Experience in the WTO Dispute Settlement System, Legal Issues of Economic Integration, 34(4), pp. 369-392.

Gao, H. (2011). Elephant in the Room: Challenges of Integrating China into the WTO System, Asian Journal of WTO \& International Health Law and Policy, 6(1), pp. 137-169.

Huang, C. and Ji, W. (2012). Understanding Chinass recent Active moves on WTO litigation: Rising Legalism or reluctant response?, Journal of World Trade, 46(6), pp. 1281-1308.

Ji, W. and Huang, C. (2011). China's Experience in Dealing with WTO Dispute Settlement: A Chinese Perspective, Journal of World Trade, 45(1), pp. 1-37.

Kennedy, M. (2012). China’s role in WTO dispute settlement, World Trade Review, 11(4), pp. 555-589.

Kong, Q. (2001). Enforcement of WTO Agreements in China: Illusion or Reality? Journal of World Trade, 35(6), pp. 1181-1214.

Lardy, N. (1999). Chinass WTO membership, Brookings Policy BriefSeries, 47 of 186, April 1999. 
Lee, Y.S. (2005). The Specific Safeguard Mechanism in the Protocol on China's Accession to the WTO: a Serious Step Backwards from the Achievement of the Uruguay Round, The Journal of World Intellectual Property, 5(2), pp. 219-231.

Ostry, S. (2003). WTO Membership for China: to be or not to be, in Cass, D.Z., Williams, B.G. and Barker, G. (eds.) China and the World Trading System - Entering the New Millennium, Cambridge University Press, pp. 31-40.

Qin, J.Y. (2003). WTO-Plus Obligations and Their Implications for the World Trade Organization Legal System, Journal of World Trade, 37(3), pp. 483-522.

Scott, J. and Wilkinson, R. (2013). China threat? Evidence from the WTO, Journal of World Trade, 47(4), pp. 761-782.

Vandenbussche, H. and Viegelahn, C. (2013). The Trade Impact of Indian Anti-Dumping Measures against China: Evidence from Monthly Trade Data, Foreign Trade Review, 48(1), pp. 1-21.

Yamaoka, T. (2013). Analysis of China's Accession Commitments in the WTO: New Taxonomy of More and Less Stringent Commitments, and the Struggle for Mitigation by China, Journal of World Trade, 47(1), pp. 105-158.

Zhao, Y. (2007). Overcoming 'Green' Barriers: China's First Five Years Into the WTO, Journal of World Trade, 41(3), pp. 535-585.

Submitted January 8, 2014

Accepted February 19, 2014

\begin{abstract}
In 2001, China finally joined the WTO. The accession of China was looked forward to by many WTO members and China itself. However, observers had some fears that the Chinese accession would prove to be a Trojan horse, disrupting the working of the WTO. This paper looks into the Chinese accession and its involvement in the WTO Dispute Settlement and argues that these fears seem so far to be unfounded.
\end{abstract}

Keywords: China; dispute settlement; international trade governance; WTO.

\title{
Resumo
}

Em 2001, a China finalmente aderiu à OMC. A adesão da China foi esperada por muitos membros da OMC e da própria China. No entanto, os observadores tinham alguns receios de que a adesão da China viria a ser um cavalo de Tróia, interrompendo o funcionamento da OMC. Este artigo analisa a adesão da China e seu envolvimento na Solução de Controvérsias da OMC e defende que estes receios parecem ser infundados.

Palavras-chave: China; solução de controvérsias; governança do comércio internacional; OMC. 